GRASAS Y ACEITES 66 (1)

January-March 2015, e058

ISSN-L: 0017-3495

doi: http://dx.doi.org/10.3989/gya.0706142

\title{
Changes in the composition of pumpkin seeds (Cucurbita moschata) during development and maturation
}

\author{
Zh.Y. Petkova ${ }^{\bowtie}$ and G.A. Antova \\ University of Plovdiv 'Paisii Hilendarski', Department of Chemical Technology, 24, Tzar Assen Str., 4000 Plovdiv, Bulgaria \\ ${ }^{凶}$ Corresponding author: jana_petkova@mail.bg
}

Submitted: 26 June 2014; Accepted: 22 September 2014

SUMMARY: Changes in the chemical and lipid composition of Cucurbita moschata seeds and seed oils at different stages of development were investigated. The oil content of the seeds at 30, 60 and 90 days after flowering was $10.7,41.1$, and $47.1 \%$, respectively. The amount of proteins was $26.0,35.9$, and $38.2 \%$. The contents of carbohydrates soluble in ethanol were $9.5,1.8$ and $1.3 \%$. The starch and fiber percentage contents were 16.3, 6.8, 2.3 and 4.0, 6.9 and 10.0, respectively and the ash contents were 7.2, 4.7, and 4.5\%. The total sterol percentages were found to be 2.0, 0.8 and 0.6 in the oils and $0.2,0.3$ and 0.3 in the seeds. The tocopherol contents were 2010, 512 and $527 \mathrm{mg} \cdot \mathrm{kg}^{-1}$ in the oil, and 215,210 and $250 \mathrm{mg} \cdot \mathrm{kg}^{-1}$ in the seeds. The total phospholipid percentages were 8.7, 0.8 and 0.4 in the oils and $0.9,0.3$ and 0.2 in the seeds. Fatty acid composition was determined by gas chromatography and the major fatty acids in the oils at all stages of ripening were linoleic (40.8-50.2\%) followed by palmitic (21.5-25.9\%) and oleic (20.5-21.0\%).

KEYWORDS: Chemical composition; Cucurbita moschata; Fatty acids; Phospholipids; Seeds developing; Sterols; Tocopherols

RESUMEN: Cambios en la composición de las semillas de calabaza (Cucurbita moschata) durante el desarrollo y la maduración. Se determinaron los cambios en la composición química y en los lípidos de semillas de Cucurbita moschata así como en los aceites extraídos en diferentes etapas del desarrollo de las semillas. El contenido de aceite a los 30, 60 y 90 días después de la floración fue de 10,7, 41,1 y 47,1\%, respectivamente. La cantidad de proteínas fue del 26,0, 35,9 y 38,2\% y el contenido de hidratos de carbono solubles en etanol fue de 9,5, 1,8 y $1,3 \%$. Los contenidos de almidón y fibras fueron $16,3,6,8,2,3 \%$ y 4,0, 6,9 y $10,0 \%$, respectivamente y el contenido de cenizas fue de $7.2 \%, 4.7 \%$ y $4.5 \%$. Se encontró un contenido total de esteroles del 2,0, 0,8 y $0,6 \%$ en los aceites y de 0,2, 0,3 y $0,3 \%$ en las semillas. El contenido de tocoferoles fue 2010,512 y $527 \mathrm{mg} \cdot \mathrm{kg}^{-1}$ en el aceite, y 215,210 y $250 \mathrm{mg} \cdot \mathrm{kg}^{-1}$ en las semillas. Los contenidos de fosfolípidos totales fueron de $8,7,0,8$ y $0,4 \%$ en los aceites y $0,9,0,3$ y $0,2 \%$ en las semillas. La composición de ácidos grasos determinada mediante cromatografía de gases mostró como principal ácido graso de los aceites en todas las etapas de maduración al linoleico (40,8 a $50,2 \%)$, seguido por palmítico $(21,5$ a $25,9 \%)$ y oleico $(20,5$ a $21,0 \%)$.

PALABRAS CLAVE: Ácidos grasos; Composición química; Cucurbita moschata; Esteroles; Fosfolípidos; Semillas en desarrollo; Tocoferoles

Citation/Cómo citar este artículo: Petkova ZhY, Antova GA. 2015. Changes in the composition of pumpkin seeds (Cucurbita moschata) during development and maturation. Grasas Aceites 66 (1): e058. doi: http://dx.doi.org/10.3989/ gya.0706142.

Copyright: (c) 2015 CSIC. This is an open-access article distributed under the terms of the Creative Commons Attribution-Non Commercial (by-nc) Spain 3.0 Licence. 


\section{INTRODUCTION}

The Cucurbitaceae family includes more than 900 species. The fruit of this family are a very valuable source of different biologically active compounds. The origin of these plants is Central and South America but they also grow in other places with warm climates. Pumpkins belong to the genus Cucurbita, family Cucurbitaceae. The genus Cucurbita includes five species: Cucurbita maxima, Cucurbita moschata, Cucurbita pepo, Cucurbita ficifolia and Cucurbita turbaniformis. The most valuable pumpkin species in Bulgaria are Cucurbita moschata, Cucurbita pepo and Cucurbita maxima. The pumpkin seeds are used for human consumption in many cultures all over the world. The seeds are by-products of the food industry and are valuable sources of different biological components such as proteins, oils, carbohydrates, microelements and vitamins. The contents of oil and protein in the seeds was $37.8-50.0 \%$ and 24.3-41.6\%, respectively (Achu et al., 2005, Achu et al., 2006, Ardabili et al., 2011, Fokou et al., 2004, Fokou et al., 2009, Martin, 1998, Tsaknis et al., 1997). The chemical characteristics of various cucurbit seed oils have been reported in many scientific investigations (Kamel et al., 1982, Lazos, 1986, Tsaknis et al., 1997). The oil content of Cucurbita moschata pumpkin seeds is about $50 \%(45-60 \%)$ according to Tsaknis et al. (1997). The oil is dark green to red, with a specific aroma and taste, and a high content of free fatty acids (Tsaknis et al., 1997). There is a lot of data about the chemical and lipid composition of Cucurbita moschata seed oil but the information about the changes in the chemical composition in the seeds and seed oils during development is scarce.

The purpose of the present study is to investigate the changes in composition of Cucurbita moschata seeds as well as those in the content and individual composition of biologically active substances (fatty acids, sterols, tocopherols and phospholipids) in the pumpkin seed oil during the development of the seeds. The changes in the fatty acid composition of the major classes of phospholipids during this period were determined as well.

\section{MATERIALS AND METHODS}

\subsection{Samples}

The fruits of Cucurbita moschata were grown and obtained from the Thracian plane (Central Southern Bulgaria), crop 2012. Samples were taken randomly between the $30^{\text {th }}$ and $90^{\text {th }}$ day after flowering, during the period from July to September, and the whole seeds were removed by hand. Prior to use for analysis, the seeds were air dried for $72 \mathrm{~h}$ at $25^{\circ} \mathrm{C}$.

All solvents and reagents were of analytical grade from Merck (Darmstadt, Germany) and were used without additional purification.

\subsection{Chemical composition of seeds}

The crude proteins were calculated from the nitrogen content according to the Kjeldahl method using factor 6.25 (AOAC, 1996). The method for determining the content of starch is based on the treatment of the plant material with an alcoholic $\mathrm{KOH}$ solution and additional acid hydrolysis of starch into glucose. The quantity of glucose is determined by the oxidation with a bivalent copper from a copper reagent and is then converted into starch (BS 13488:1976). The carbohydrates which are soluble in ethanol were identified by their extraction with $80 \% \mathrm{C}_{2} \mathrm{H}_{5} \mathrm{OH}$, converted into glucose which is determined on the basis of its copper-alkaline solutions (Islam et al., 2008). Crude fiber was determined by the gravimetric procedure of AOAC (1995). Ash content was evaluated by incinerating at $550{ }^{\circ} \mathrm{C}$ in a muffle furnace for $6 \mathrm{~h}$ (AOAC, 1995).

\subsection{Isolation of glyceride oil and determination of oil content}

The seeds (50 g sample) were air-dried at room temperature, ground to powder with a mechanical mill and the oil was extracted with n-hexane in a Soxhlet apparatus for $8 \mathrm{~h}$. The solvent was partially removed in a rotary vacuum evaporator, the residue was transferred to pre-weighed glass vessels and the rest of the solvent was removed under a stream of nitrogen to a constant weight to determine the oil content (ISO, 2009).

\subsection{Analysis of fatty acids}

The fatty acid composition of glyceride oil, as well as the fatty acid composition of phospholipids, was determined by gas chromatography (GC) after transmethylation of the respective sample with $2 \%$ $\mathrm{H}_{2} \mathrm{SO}_{4}$ in absolute $\mathrm{CH}_{3} \mathrm{OH}$ at $50{ }^{\circ} \mathrm{C}$ (ISO, 2000a). Fatty acid methyl esters (FAME) were purified by thin-layer chromatography (TLC) on $20 \times 20 \mathrm{~cm}$ plates covered with a $0.2 \mathrm{~mm}$ silica gel $60 \mathrm{G}$ (Merck, Darmstadt, Germany) layer with the mobile phase n-hexane:diethyl ether (97:3, v/v). GC was performed on an HP 5890 series II gas chromatograph (Hewlett Packard GesmbH, Vienna, Austria) equipped with a $60 \mathrm{~m} \times 0.25 \mathrm{~mm}$ (I.D.) $\times 25 \mu \mathrm{m}$ (film thickness) capillary DB - 23 column (Agilent J\&W advanced, Agilent Technology, USA) and a flame ionization detector. The column temperature was programmed from $130{ }^{\circ} \mathrm{C}(1 \mathrm{~min})$, at $6.5^{\circ} \mathrm{C} \cdot \mathrm{min}^{-1}$ to $170{ }^{\circ} \mathrm{C}$, at $3.0^{\circ} \mathrm{C} \cdot \mathrm{min}^{-1}$ to $215^{\circ} \mathrm{C}(9 \mathrm{~min})$, at $40{ }^{\circ} \mathrm{C} \cdot \mathrm{min}^{-1}$ to $230^{\circ} \mathrm{C}(1 \mathrm{~min})$; the injector and detector temperatures were kept at $270{ }^{\circ} \mathrm{C}$ and $280{ }^{\circ} \mathrm{C}$. Hydrogen was the carrier gas at a flow rate $0.8 \mathrm{~mL} \cdot \mathrm{min}^{-1}$; the split ratio was 1:50. The identification of fatty acids was performed by comparison of retention times 
with those of a standard mixture of fatty acids subjected to GC under identical experimental conditions (ISO, 2004). The analytical standard of fatty acid methyl esters (Supelco F.A.M.E. Mix C4-C24, purity $\sim 99 \%$ ) was from Sigma-Aldrich Chemical Co. (St. Louis, MO, USA).

\subsection{Analysis of sterols}

Unsaponifiables were determined by weight after saponification of the glyceride oil and extraction with hexane (ISO, 2000b). The sterol fraction was separated from the unsaponifiable matter by thinlayer chromatography on silica gel $60 \mathrm{G}$ in the mobile phase diethyl ether:hexane $(1: 1, \mathrm{v} / \mathrm{v})$. The qualitative and quantitative composition of the sterol fraction was determined by GC on an HP 5890 series II gas chromatograph (Hewlett Packard GesmbH, Vienna, Austria) equipped with $25 \mathrm{~m} \times 0.25 \mathrm{~mm}$ (I.D.) $\times 25 \mu \mathrm{m}$ (film thickness) DB-5 capillary column (Agilent Technologies, J\&W Scientific products Proudly, Santa Clara CA, USA) and flame ionization detector. The temperature gradient ranged from $90{ }^{\circ} \mathrm{C}$ (held for $2 \mathrm{~min}$ ) up to $290{ }^{\circ} \mathrm{C}$ at a rate of change of $15^{\circ} \mathrm{C} \cdot \mathrm{min}^{-1}$ and then up to $310^{\circ} \mathrm{C} \mathrm{a}$ rate of $4{ }^{\circ} \mathrm{C} \cdot \mathrm{min}^{-1}$ (held for $10 \mathrm{~min}$ ); detector temperature, $320^{\circ} \mathrm{C}$; injector temperature, $300{ }^{\circ} \mathrm{C}$ and carrier gas, hydrogen $\left(\mathrm{H}_{2}\right)$, split ratio, 1:50 and software Data Apex Clarity TM 2.4.1.93/2005. A mixture of sterols containing cholesterol (New Jersey, USA), stigmasterol (Acros organics, St. Louis, MO, USA) and $\beta$-sitosterol (with ca $10 \%$ campesterol, ca $75 \% \beta$-sitosterol, New Jersey, USA) was used for the determination of the retention times of the individual sterols in the samples and for quantitative calculations (ISO, 1999).

\subsection{Analysis of tocopherols}

Tocopherols were determined directly in the oil by high performance liquid chromatography (HPLC) on a "Merck-Hitachi" (Merck, Darmstadt, Germany) instrument equipped with a $250 \mathrm{~mm} \times 4 \mathrm{~mm}$ Nucleosil Si 50-5 column (Merck, Darmstadt, Germany) and fluorescent detector "Merck-Hitachi" F 1000. The operating conditions were as follows: mobile phase of n-hexane:dioxan $(96: 4, \mathrm{v} / \mathrm{v})$, a flow rate of 1.0 $\mathrm{mL} \cdot \mathrm{min}^{-1}$, excitation $295 \mathrm{~nm}$, emission $330 \mathrm{~nm}$ (ISO 9936:2006). $20 \mu \mathrm{L}$ of a $1 \%$ solution of oil in hexane were injected. The individual tocopherols were identified by comparing the retention times with those of standards (reference individual pure tocopherols - DL- $\alpha$-, DL- $\beta$, DL- $\gamma$ - and DL- $\delta$-tocopherol with $\geq 98 \%$ purity) purchased from Merck (Darmstadt, Germany). The content of tocopherols in the seed oils was calculated by comparing the peak areas obtained for the relevant tocopherols in the sample with those obtained for the standard solutions with known concentrations.

\subsection{Analysis of phospholipids}

Another part $(50 \mathrm{~g})$ of the air-dried seeds was subjected to Folch extraction (Folch et al., 1957) and polar lipids were isolated from the total lipids by column chromatography (Angelova-Romova et al., 2013). The phospholipid classes were isolated using two-dimensional TLC on $20 \times 20 \mathrm{~cm}$ glass plates with a $0.2 \mathrm{~mm}$ silica gel $60 \mathrm{G}$ layer impregnated with aqueous $\left(\mathrm{NH}_{4}\right)_{2} \mathrm{SO}_{4}(1 \%$ solution in water). In the first phase the plate was developed with chloroform:methanol:ammonia, $(65: 25: 5, \mathrm{v} / \mathrm{v} / \mathrm{v})$ and in the second with chloroform:acetone:methan ol:acetic acid:water $(50: 20: 10: 10: 5, \mathrm{v} / \mathrm{v} / \mathrm{v} / \mathrm{v} / \mathrm{v})$. The individual phospholipids were detected and identified by spraying with specific reagents from Sigma Aldrich: Dragendorff test (detection of cholinecontaining phospholipids), Ninhydrin spray (for phospholipids with free amino groups) and Shiff's reagent (for inositol containing phospholipids). An additional identification was made by comparing the respective $R_{f}$ values with those of authentic standards (Sigma, St. Louis, MO, USA) subjected to silica gel TLC under identical experimental conditions. The quantification was carried out spectrophotometrically against a standard curve by measuring the phosphorous content at $700 \mathrm{~nm}$ after scrapping the respective phospholipid spot and mineralization of the substance with a mixture of perchloric acid and sulphuric acid $(1: 1, \mathrm{v} / \mathrm{v})$. The analytical curve was constructed using a standard solution of $\mathrm{KH}_{2} \mathrm{PO}_{4}$ and in each series of measurements a standard solution of $\mathrm{KH}_{2} \mathrm{PO}_{4}\left(10 \mu \mathrm{g} \cdot \mathrm{mL}^{-1}\right.$ in water) was used to confirm the validity of calibration. The phospholipid content in the sample was calculated as a percentage of the phosphorus (ISO, 2003).

\subsection{Statistical analyses}

All the analyses of the studied samples were performed in triplicate. The results were represented as mean \pm standard deviation (SD). Differences between mean values were considered significant at $\mathrm{P}=0.05$.

\section{RESULTS AND DISCUSSION}

\subsection{Changes in the chemical composition of pumpkin seeds (Cucurbita moschata) during the growing period}

The changes of the main compounds of pumpkin seeds during development are presented in Table 1.

The protein contents in the seeds increased throughout the period of growing from $26.0 \%$, at the $30^{\text {th }}$ day after flowering to $38.2 \%$, at the $90^{\text {th }}$ day. This result is in good agreement with the data of other publications where the protein content in 
TABLE 1. Changes in chemical composition of pumpkin seeds (Cucurbita moschata) during the growing period*

\begin{tabular}{lccc}
\hline & \multicolumn{3}{c}{ Growing period, days after flowering } \\
\cline { 2 - 4 } Compounds (wt \%) & $\mathbf{3 0}$ & $\mathbf{6 0}$ & $\mathbf{9 0}$ \\
\hline Protein & $26.0 \pm 0.3$ & $35.9 \pm 0.2$ & $38.2 \pm 0.1$ \\
Fat & $10.7 \pm 0.2$ & $41.1 \pm 0.1$ & $47.1 \pm 0.3$ \\
Carbohydrate & & & \\
starch & $16.3 \pm 0.2$ & $6.8 \pm 0.1$ & $2.3 \pm 0.1$ \\
soluble carbohydrates (in $\left.80 \% \mathrm{C}_{2} \mathrm{H}_{5} \mathrm{OH}\right)$ & $9.5 \pm 0.7$ & $1.8 \pm 0.1$ & $1.3 \pm 0.2$ \\
crude fibres & $4.0 \pm 0.1$ & $6.9 \pm 0.2$ & $10.0 \pm 0.1$ \\
Ash & $7.2 \pm 0.1$ & $4.7 \pm 0.2$ & $4.5 \pm 0.1$ \\
\hline
\end{tabular}

*Value for each nutrient is the mean $\pm \mathrm{SD}$ (standard deviations) of three determinations $(\mathrm{n}=3$ and $\mathrm{p}<0.05$ ).

ripe seeds varies from $25.0 \%$ to $51.0 \%$ (Aboul-Nasr et al., 1997; Achu et al., 2005; Bombardelli and Morazzoni, 1997; Kim et al., 2012; Nakiae et al., 2006).

During the first thirty days, pumpkin seeds have lower lipid contents $(10.7 \%)$, in the second 30 days the oil content increased rapidly to $41.1 \%$ and then more slowly to $47.1 \%$. These results confirm the data reported earlier by Achu et al. (2005) and Kim et al. (2012) according to whom the oil content was $41.98-54.45 \%$.

The carbohydrate content at the $30^{\text {th }}$ day of flowering was comparatively higher $(\sim 29.8 \%)$ and in the following days decreased gradually to about $13.6 \%$. The starch content is higher in the first 30 days $(16.3 \%$ in the seeds) while in the next 60 days decreased by two to seven times. A similar tendency was observed for the soluble carbohydrates in $80 \%$ ethanol. Their amount was $9.5 \%$ in the first 30 days and decreased with the maturing of the pumpkin seeds to $1.3 \%$. The content of crude fibres in the seeds increased from $4.0 \%$ to $10.0 \%$. These results are in good agreement with the data of other publications where the carbohydrate content was $6.05-23.00 \%$ and the content of fiber varied from $1.22 \%$ to $10.85 \%$. (Achu et al., 2005; Al-Khalifa, 1996; Kim et al., 2012).

The ash content in the seeds during development decreased slightly from 7.2 to $4.5 \%$. These results were similar to the data of other publications (4.21-5.32\%) (Achu et al., 2005; Kim et al., 2012).

The results from investigations on the general chemical composition of the pumpkin seeds (Cucurbita moschata) showed higher content of oil, protein and fibres and lower contents of minerals (ash) and carbohydrates in the final stage of ripening than that in the first and second stages.

\subsection{Changes in the lipid composition of pumpkin seeds during the growing period}

The data on the change in oil content in the seeds and biologically active components (such as sterols, tocopherols and phospholipids) in the pumpkin oil and the seeds during maturation are shown in Table 2.

The oil content increased with the development of the pumpkin seeds $(10.7-47.1 \%)$ while the quantity of the unsaponifiable matter in the oil decreased from $16.5 \%$ to $2.2 \%$. The content of unsaponifiable matter in the seeds decreased slightly from $1.8 \%$ to $1.0 \%$. The quantity of unsaponifiable matter in the mature seeds was higher than that shown in previous publications (Al-Khalifa, 1996).

The same trend has been shown for the sterol fraction. The sterol content in the oil decreased from $2.0 \%$ to $0.6 \%$ while in the seeds in the first stage it was $0.2 \%$ and in the next two stages it was $0.3 \%$. In the beginning the sterol content was $12.0 \%$ of the total unsaponifiable matter, after which its quantity increased to $24.3 \%$ then; in the final stage of growing the sterol content was $26.6 \%$. Obviously, sterols were synthesized mainly in the beginning of the ripening and the rate of biosynthesis continued to slow down during the next two stages of development.

The total tocopherol content in the seed oil on the $30^{\text {th }}$ day of flowering was extremely high, at $2010 \mathrm{mg} \cdot \mathrm{kg}^{-1}$, but in the next two stages of development it decreased by around four times, to $512 \mathrm{mg} \cdot \mathrm{kg}^{-1}$ and $527 \mathrm{mg} \cdot \mathrm{kg}^{-1}$, respectively.

In the first stage of development, the total phospholipids were represented in a higher quantity ( $8.7 \%$ in oil and $0.9 \%$ in the seeds) compared with the next two stages where the total phospholipid contents decreased to $0.4 \%$ in the oil and $0.2 \%$ in the seeds. The high percentage content of phospholipids in the first stage was due to the fact that they were synthesized mainly in the beginning of vegetation. Triacylglycerols were synthesized in a later stage, with the result that the relative amount of phospholipids in the oil significantly decreased.

\subsubsection{Fatty acid composition}

The data about fatty acid composition of Cucurbita moschata seed oil during the growing period is shown in Table 3. 
Changes in the composition of pumpkin seeds (Cucurbita moschata) during development and maturation $\bullet 5$

TABLE 2. Changes in content of biologically active substances in the pumpkin oil and seeds during the growing period*

\begin{tabular}{lccc}
\hline & \multicolumn{3}{c}{ Growing period, days after flowering } \\
\cline { 2 - 4 } Compounds & $\mathbf{3 0}$ & $\mathbf{6 0}$ & $\mathbf{9 0}$ \\
\hline Oil in the seeds, wt \% & $10.7 \pm 0.2$ & $41.1 \pm 0.1$ & $47.1 \pm 0.3$ \\
Unsaponifiable matters & & & \\
$\quad$ in the oil, wt \% & $16.5 \pm 0.2$ & $2.4 \pm 0.1$ & $2.2 \pm 0.3$ \\
$\quad$ in the seeds, wt \% & $1.8 \pm 0.04$ & $1.0 \pm 0.01$ & $1.0 \pm 0.09$ \\
Sterols & & & \\
in the unsaponifiable matters, wt \% & $12.0 \pm 0.2$ & $24.3 \pm 0.3$ & $26.6 \pm 0.1$ \\
in the oil, wt \% & $2.0 \pm 0.2$ & $0.8 \pm 0.3$ & $0.6 \pm 0.1$ \\
$\quad$ in the seeds, wt \% & $0.2 \pm 0.04$ & $0.3 \pm 0.03$ & $0.3 \pm 0.03$ \\
Tocopherols & & & $11.6 \pm 0.6$ \\
in the unsaponifiable matters, $\mathrm{mg} \cdot \mathrm{kg}^{-1}$ & $331.7 \pm 4.6$ & $12.3 \pm 0.3$ & $527 \pm 20$ \\
$\quad$ in the oil, $\mathrm{mg} \cdot \mathrm{kg}{ }^{-1}$ & $2010 \pm 20$ & $512 \pm 10$ & $250 \pm 6$ \\
$\quad$ in the seeds, $\mathrm{mg} \cdot \mathrm{kg}^{-1}$ & $215 \pm 4$ & $210 \pm 1$ & \\
Phospholipids & & & $0.4 \pm 0.2$ \\
$\quad$ in the oil, wt \% & $8.7 \pm 0.2$ & $0.8 \pm 0.2$ & $0.2 \pm 0.06$ \\
$\quad$ in the seeds, w t\% & $0.9 \pm 0.04$ & $0.3 \pm 0.02$ & \\
\hline
\end{tabular}

*Value for each nutrient is the mean \pm SD (standard deviations) of three determinations $(\mathrm{n}=3$ and $\mathrm{p}<0.05$ ).

TABLE 3. Changes in the fatty acid composition and saturated (SFA), unsaturated (UFA), monounsaturated (MUFA) and polyunsaturated fatty acids (PUFA) of pumpkin seed oil during the development of seeds

\begin{tabular}{lccc}
\hline & \multicolumn{3}{c}{ Growing period, days after flowering } \\
\cline { 2 - 4 } Fatty acids*, \% & $\mathbf{3 0}$ & $\mathbf{6 0}$ & $\mathbf{9 0}$ \\
\hline $\mathrm{C}_{8: 0}$ & $0.1 \pm 0.02$ & $0.1 \pm 0.04$ & - \\
$\mathrm{C}_{12: 0}$ & $0.1 \pm 0.01$ & - & - \\
$\mathrm{C}_{14: 0}$ & $0.3 \pm 0.1$ & $0.2 \pm 0.05$ & $0.2 \pm 0.05$ \\
$\mathrm{C}_{15: 0}$ & $0.1 \pm 0.02$ & - & - \\
$\mathrm{C}_{16: 0}$ & $25.9 \pm 0.4$ & $24.7 \pm 0.2$ & $21.5 \pm 0.5$ \\
$\mathrm{C}_{17: 0}$ & $0.1 \pm 0.01$ & $0.1 \pm 0.02$ & $0.1 \pm 0.01$ \\
$\mathrm{C}_{18: 0}$ & $9.3 \pm 0.4$ & $9.2 \pm 0.2$ & $6.7 \pm 0.5$ \\
$\mathrm{C}_{18: 1}$ & $20.5 \pm 0.2$ & $21.0 \pm 0.3$ & $21.0 \pm 0.1$ \\
$\mathrm{C}_{18: 2},(\mathrm{n}-6)$ & $40.8 \pm 0.5$ & $43.6 \pm 0.2$ & $50.2 \pm 0.2$ \\
$\mathrm{C}_{18: 3},(\mathrm{n}-3)$ & $1.9 \pm 0.2$ & $0.3 \pm 0.1$ & $0.2 \pm 0.05$ \\
$\mathrm{C}_{20: 0}$ & $0.4 \pm 0.1$ & $0.4 \pm 0.1$ & $0.1 \pm 0.02$ \\
$\mathrm{C}_{20: 1}$ & $0.1 \pm 0.02$ & $0.1 \pm 0.02$ & - \\
$\mathrm{C}_{22: 0}$ & $0.4 \pm 0.1$ & $0.3 \pm 0.1$ & - \\
$\mathrm{SFA}$ & 36.7 & 35.0 & 28.6 \\
$\mathrm{UFA}$ & 63.3 & 65.0 & 71.4 \\
$\mathrm{MUFA}$ & 20.6 & 21.1 & 21.0 \\
$\mathrm{PUFA}$ & 42.7 & 43.9 & 50.4 \\
\hline
\end{tabular}

${ }^{*} \mathrm{C}_{8: 0}$ - Caprylic acid; $\mathrm{C}_{12: 0}$ - Lauric acid; $\mathrm{C}_{14: 0}$ - Myristic acid; $\mathrm{C}_{15: 0}$ - Pentadecanoic acid; $\mathrm{C}_{16: 0}$ - Palmitic acid; $\mathrm{C}_{17: 0}$ - Margaric acid; $\mathrm{C}_{18: 0}$ - Stearic acid; $\mathrm{C}_{18: 1}$ - Oleic acid; $\mathrm{C}_{18: 2}$-Linoleic acid; $\mathrm{C}_{18: 3}$ Linolenic acid; $\mathrm{C}_{20: 0}$ - Arachidic acid; $\mathrm{C}_{20: 1}$ - Gadoleic acid; $\mathrm{C}_{22: 0}$ - Behenic acid; SFA - saturated fatty acids; UFA - unsaturated fatty acids; MUFA - monounsaturated fatty acids; PUFA polyunsaturated fatty acids.
Linoleic acid prevailed in the seed oil (40.8-50.2\%), followed by palmitic (21.5-25.9\%), oleic (20.5-21.0\%) and stearic (6.7-9.3\%) acids. The quantity of palmitic and stearic acids decreased during the ripening process. The level of oleic acid remained the same during development while the quantity of linoleic acid was increasing significantly from $40.8 \%$ to $50.2 \%$. The content of the linolenic acid, which represents one of the essential fatty acids, was minimal (on the $30^{\text {th }}$ day of flowering it was $1.9 \%$ and after that it decreased to $0.2 \%$ ). Changes in the fatty acid composition were a consequence of the different stages of biosynthesis of the fatty acids - in the first stage of ripening the saturated fatty acids were accumulated, after that the rate of biosynthesis of the polyunsaturated fatty acids increased. In addition to the main fatty acids in Cucurbita moschata seed oil, many others fatty acids such as caprylic, lauric, myristic, pentadecanoic, margaric, arachidic, gadoleic and behenic acids were detected but they are represented in very small amounts. During the process of investigation they did not undergo any significant changes.

The data on the fatty acid composition of Cucurbita moschata seed oil is similar to those reported in previous publications. The content of linoleic acid is higher than the other fatty acids and varies from $35.7 \%$ to $56.6 \%$ followed by oleic acid (14.8-38.1\%), palmitic acid (10.7-16.4\%) and stearic acid (4.7-11.1\%) (Achu et al., 2006; Al-Khalifa, 1996; Kim et al., 2012).

The ratio between saturated (SFA) and unsaturated (UFA) fatty acids including monounsaturated 
and polyunsaturated fatty acids during the growing period is presented in Table 3 .

The quantity of SFA decreased during the process of ripening from $36.7 \%$ to $28.6 \%$ while that of UFA increased from $63.3 \%$ to $71.4 \%$. This higher content of UFA is due to the increase in PUFA, i.e. linoleic acid. The ratio between UFA and SFA increased slightly during ripening and in the first stage this ratio was $1.7: 1$, in the second stage it was 1.9:1 and in the mature pumpkin seeds it was 2.5:1. These results are in a good agreement with data reported by Al-Khalifa (1996) (SFA - 19.1-19.7\%, MUFA - 26.64-53.33\% and PUFA - 36.1-44.0\%), Achu et al. (2006) (SFA - 21.7-30.2\%, MUFA $19.4-25.3 \%$ and PUFA - 49,38-52,63\%), Kim et al. (2012) (SFA - 17.47-20.11\%, MUFA - 14.9-32.4\% and PUFA - 35.72-56.84\%).

\subsubsection{Sterol composition}

The changes in individual sterol composition during the development of seeds are shown in Table 4.

The main component in the sterol fraction was $\alpha$-spinasterol, which on the $30^{\text {th }}$ day of flowering was $71.9 \%$ and after that its quantity decreased to $44.8 \%$ on the $90^{\text {th }}$ day. At the same time, the quantity of $\Delta^{7,25}$-stigmastadienol increased from $5.1 \%$ to $25.9 \%$. The $\Delta^{7}$-stigmasterol content on the $30^{\text {th }}$ day after flowering was $10.8 \%$, on the $60^{\text {th }}$ day it was $26.2 \%$ and its content was $6.9 \%$ on the $90^{\text {th }}$ day. The content of stigmasterol remained the same during development and it was around 7.0-8.0\%. $\beta$-sitosterol was presented in very small amounts $(0.3-0.1 \%)$. The cholesterol content was minimal (from $0.5 \%$ to $0.2 \%$ ).

These results differ from the data of other publications about the sterol composition from foreign species of pumpkin seeds. The quantity of $\beta$-sitosterol at the final growth stage is $277.58 \mathrm{mg} \cdot \mathrm{kg}^{-1}$ according to Kim et al. (2012) and $249.0 \mathrm{mg} \cdot \mathrm{kg}^{-1}$ as published by Ryan et al. (2007).

TABLE 4. Changes in individual sterol composition of Cucurbita moschata seed oil during the development of seeds

\begin{tabular}{lccc}
\hline & \multicolumn{3}{c}{ Growing period, days after flowering } \\
\cline { 2 - 4 } Sterols, \% & $\mathbf{3 0}$ & $\mathbf{6 0}$ & $\mathbf{9 0}$ \\
\hline Cholesterol & $0.5 \pm 0.02$ & $0.2 \pm 0.01$ & $0.2 \pm 0.04$ \\
Campesterol & $1.8 \pm 0.3$ & $0.6 \pm 0.1$ & $0.5 \pm 0.05$ \\
Stigmasterol & $7.3 \pm 0.1$ & $7.7 \pm 0.2$ & $7.2 \pm 0.1$ \\
$\alpha$ - Spinasterol & $71.9 \pm 0.2$ & $45.2 \pm 0.1$ & $44.8 \pm 0.3$ \\
$\beta$ - Sitosterol & $0.3 \pm 0.02$ & $0.1 \pm 0.01$ & - \\
$\Delta^{5}$ - Avenasterol & $0.4 \pm 0.05$ & $0.3 \pm 0.04$ & $0.3 \pm 0.02$ \\
$\Delta^{7,25}$ - Stigmastadienol & $5.1 \pm 0.1$ & $11.6 \pm 0.2$ & $25.9 \pm 0.1$ \\
$\Delta^{7}$ - Stigmasterol & $10.8 \pm 0.3$ & $26.2 \pm 0.1$ & $6.9 \pm 0.2$ \\
$\Delta^{7}$ - Avenasterol & $1.9 \pm 0.1$ & $8.1 \pm 0.2$ & $14.2 \pm 0.3$ \\
\hline
\end{tabular}

The individual sterol composition of the investigated oils differs significantly from the sterol composition of the other vegetable oils (sunflower, rape, safflower, soybean, grapes, maize) in which $\beta$ sitosterol predominated (32.6-87.1\%) (Codex-Stan $210-1999)$. In the pumpkin seed oils $\alpha$-spinasterol $(44.8-71.9 \%)$ and $\Delta^{7,25}$-stigmastadienol (5.1-25.9\%) prevailed while in other vegetable oils these two sterols are represented in very small quantities or they are not found.

\subsubsection{Tocopherol composition}

The changes in the content of tocopherols in the pumpkin oils are presented in Table 5.

$\gamma$-Tocopherol was presented in considerable amounts in all three growth stages. Its quantity at the beginning was $944.7 \mathrm{mg} \cdot \mathrm{kg}^{-1}$, which later decreased to $383.5 \mathrm{mg} \cdot \mathrm{kg}^{-1}$ and in the final stage it was $453.7 \mathrm{mg} \cdot \mathrm{kg}^{-1}$. At the same time, the quantity of $\alpha$-tocopherol decreased significantly from 894.5 to $20.0 \mathrm{mg} \cdot \mathrm{kg}^{-1}$ while that of $\gamma$-tocotrienol decreased slightly from 120.6 to $52.7-53.3 \mathrm{mg} \cdot \mathrm{kg}^{-1}$. On the $30^{\text {th }}$ day of flowering the amounts of $\alpha$-tocopherol and $\gamma$-tocopherol are the same but in the next two growth stages the quantity of $\gamma$-tocopherol decreased by half compared to the first stage. The content of $\gamma$-tocopherol in the seeds in the final stage of ripening was $215.3 \mathrm{mg} \cdot \mathrm{kg}^{-1}$ while the content of $\alpha$-tocopherol was $9.5 \mathrm{mg} \cdot \mathrm{kg}^{-1}$ in the seeds. These results differ from the data reported by Kim et al. (2012). According to these authors, Cucurbita pepo and Cucurbita moschata seeds contain higher levels of $\gamma$-tocopherol (61.65-66.85 $\mathrm{mg} / \mathrm{kg}$ in the seeds) than Cucurbita maxima seeds $\left(28.7 \mathrm{mg} \cdot \mathrm{kg}^{-1}\right)$. The $\gamma$-tocopherol content of Cucurbita pepo seeds $\left(61.65 \mathrm{mg} \cdot \mathrm{kg}^{-1}\right.$ raw weight) and Cucurbita moschata seeds (66.85 $\mathrm{mg} \cdot \mathrm{kg}^{-1}$ raw weight) is two to three times higher than the $\alpha$-tocopherol content $\left(21.33-25.74 \mathrm{mg} \cdot \mathrm{kg}^{-1}\right)$ (Kim et al., 2012).

The individual tocopherol composition of the investigated pumpkin seed oils in the final growth stage differs significantly from that of the various known vegetable oils. $\alpha$-Tocopherol predominates in the other vegetable oils except for soybean, sesame, and corn germ oils, whose tocopherol

TABLE 5. Changes in the content of tocopherols of Cucurbita moschata seed oil during the ripening process

\begin{tabular}{lccc}
\hline & \multicolumn{3}{c}{ Growing period, days after flowering } \\
\cline { 2 - 4 } Tocopherol, $\mathbf{~ m g} \cdot \mathbf{k g}^{-1}$ & $\mathbf{3 0}$ & $\mathbf{6 0}$ & $\mathbf{9 0}$ \\
\hline$\alpha$ - tocopherol & $894.5 \pm 21.2$ & $75.8 \pm 6.3$ & $20.0 \pm 2.6$ \\
$\gamma$ - tocopherol & $944.7 \pm 23.7$ & $383.5 \pm 18.5$ & $453.7 \pm 17.6$ \\
$\gamma$ - tocotrienol & $120.6 \pm 12.4$ & $52.7 \pm 4.8$ & $53.3 \pm 4.3$ \\
$\delta$ - tocopherol & $50.2 \pm 5.6$ & trace & trace \\
\hline
\end{tabular}


composition is closer to the composition of pumpkin seed oil where $\gamma$-tocopherol prevails.

\subsubsection{Phospholipid composition and fatty acid composition of the major classes of phospholipids}

The composition of the phospholipid fraction of lipids from Cucurbita moschata seed oils during development is shown in Table 6.

Phosphatidic acids $(38.7 \%)$ prevail during the first phase of ripening. Since phosphatidic acids are the first to be biosynthesized and are a precursor for the biosynthesis of phosphatidylcholine, phosphatidylinositol and phosphatidylethanolamine (Munshi et al., 1983), as expected, its amount is higher in the early stages of seed development and then decreases gradually. The other classes of phospholipids are presented in quantities around 10.0-15.0\% except for lysophosphatidylcholine, whose amount was $1.5 \%$. There was an abrupt increase in the quantity of phosphatidylinositol from $14.8 \%$ in the first stage to $47.6 \%$ and $48.4 \%$ in the next two growth stages and a slight increase in phosphatidylethanolamine from 11.9 to $13.5-17.8 \%$ and in phosphatidylcholine from 9.9 to $11.0-17.1 \%$ at the expense of the decrease in phosphatidic acids (14.6-6.6\%). Changes in the content of phosphatidylserine from 0.0 to $4.6-4.9 \%$ and sphingomyelin from 0.0 to 0.5 $0.9 \%$ were minimal.

These results differ from the data reported by Raharjo et al. (2011) who investigated phospholipids from Cucurbita moschata seeds and established the main phospholipids to be phosphatidylcholine, phosphatidylserine and phosphatidylethanolamine.

Palmitic (35.1-61.4\%), linoleic (7.1-28.7\%), stearic $(8.3-13.2 \%)$ and oleic $(3.0-27.0 \%)$ acids were mainly identified in the major individual phospholipids (phosphatidylcholine, phosphatidylethanolamine, phosphatidylinositol and phosphatidic acids) as shown in Fig. 1. These acids prevail in the phospholipid fraction during the entire process

TABLE 6. Changes in the phospholipid composition of Cucurbita moschata seed oils during development

\begin{tabular}{lccc}
\hline & \multicolumn{3}{c}{ Growing period, days after flowering } \\
\cline { 2 - 4 } Phospholipids, \% & $\mathbf{3 0}$ & $\mathbf{6 0}$ & $\mathbf{9 0}$ \\
\hline Phosphatidylcholine & $9.9 \pm 0.1$ & $11.0 \pm 0.2$ & $17.1 \pm 0.1$ \\
Phosphatidylinositol & $14.8 \pm 0.2$ & $47.6 \pm 0.3$ & $48.4 \pm 0.5$ \\
Phosphatidylethanolamine & $11.9 \pm 0.1$ & $13.5 \pm 0.4$ & $17.8 \pm 0.5$ \\
Phosphatidic acids & $38.7 \pm 0.3$ & $14.6 \pm 0.2$ & $6.6 \pm 0.1$ \\
Phosphatidylserine & - & $4.6 \pm 0.2$ & $4.9 \pm 0.3$ \\
Lysophosphatidylcholine & $1.5 \pm 0.1$ & - & - \\
Sphingomyelin & - & $0.5 \pm 0.1$ & $0.9 \pm 0.2$ \\
Monophosphatidylglycerol & $10.7 \pm 0.3$ & $5.4 \pm 0.2$ & $3.1 \pm 0.1$ \\
Diphosphatidylglycerol & $12.5 \pm 0.5$ & $2.8 \pm 0.3$ & $1.2 \pm 0.1$ \\
\hline
\end{tabular}

of ripening. Myristic, linolenic and the rest of the fatty acids are presented in very small quantities. On the other hand, the fatty acid composition of the triacylglycerols, where linoleic acid prevails $(40.8-50.2 \%)$, differs from the fatty acid composition of the main phospholipids.

The quantity of palmitic acid in phosphatidylcholine, phosphatidylinositol and phosphatidylethanolamine increased on the $60^{\text {th }}$ day and after that on the $90^{\text {th }}$ day remained in the same amount. The phosphatidic acid content was high during the first 30 days only (Fig. 1). The quantity of stearic acid decreased until the second growth phase, and then remained at the same level or dropped in the final stage of development.

The quantity of oleic acid in phosphatidylcholine, phosphatidylinositol and phosphatidylethanolamine decreased on the $60^{\text {th }}$ day of flowering, after which it increased again. The amount of oleic acid in phosphatidic acids increased significantly during the investigated period. The quantity of linoleic acid in phosphatidylcholine and phosphatidylinositol increased until the $60^{\text {th }}$ day, and then decreased on the $90^{\text {th }}$ day while in phosphatidylethanolamine and phosphatidic acids (Fig. 1) it increased throughout the period of the study.

The amount of linolenic acid in all the major classes of phospholipids decreased during seed development.

The content of saturated fatty acids was more than $55.0 \%$ and that of unsaturated fatty acids from $16.2 \%$ to $44.5 \%$ (Fig. 2).

These results are different from the data in other publications about fatty acid composition of separate individual classes of phospholipids. Raharjo et al. (2011) established the main fatty acids in phosphatidylcholine to be oleic $(38.21 \%)$ and palmitic $(24.10 \%)$ while in the fraction of phosphatidylethanolamine oleic $(45.23 \%)$ and linoleic $(30.44 \%)$ acids prevailed; in the phosphatidylserine, palmitic $(30.17 \%)$, oleic $(28.83 \%)$ and linoleic $(28.22 \%)$ acids are presented in almost equal amounts.

\section{CONCLUSIONS}

In the maturing process of Cucurbita moschata pumpkin seeds, their nutritional value increased in oil content, protein and fiber and decreased in minerals and carbohydrates. Pumpkin oil is a potential source of essential fatty acids such as linoleic, and is rich in lipid-soluble bioactive compounds. The contents of biologically active compounds in the oil and the seeds dropped during growth. The fatty acid profile of glyceride oil changed. During the ripening process the amount of saturated fatty acids decreased from $36.7 \%$ to $28.6 \%$, while that of unsaturated fatty acids increased from $63.3 \%$ to $71.4 \%$. The content of essential linoleic fatty acid in pumpkin oil increased from 40.8 to $50.2 \%$. 


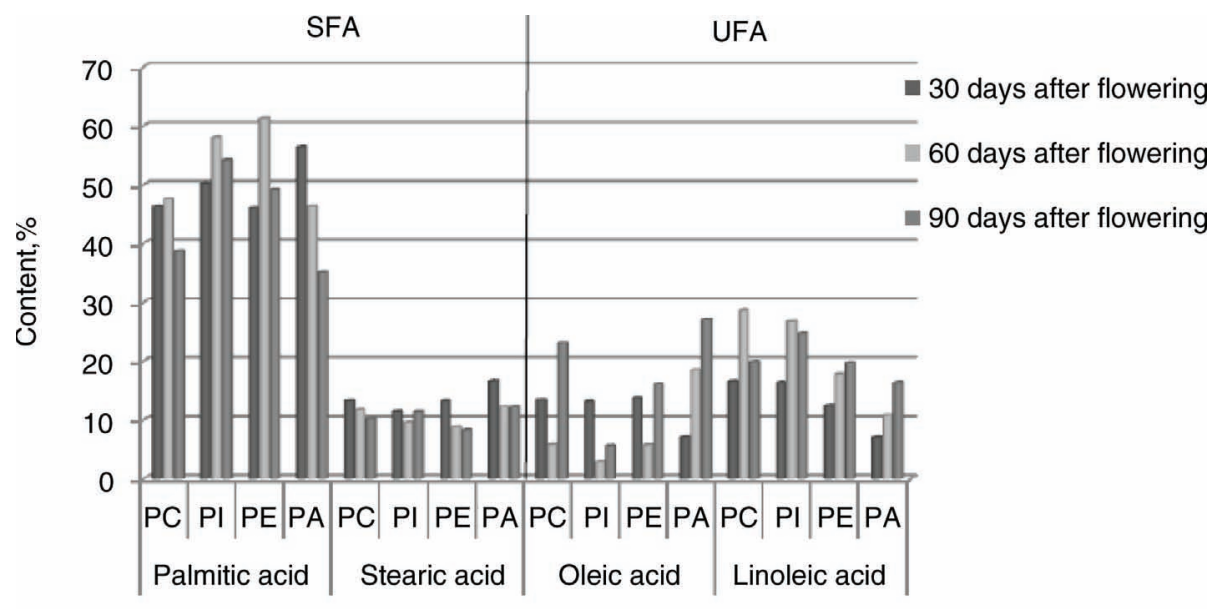

Fatty acids

FIGURE 1. Changes in main saturated (SFA) and unsaturated (UFA) fatty acids in the major classes of phospholipids.
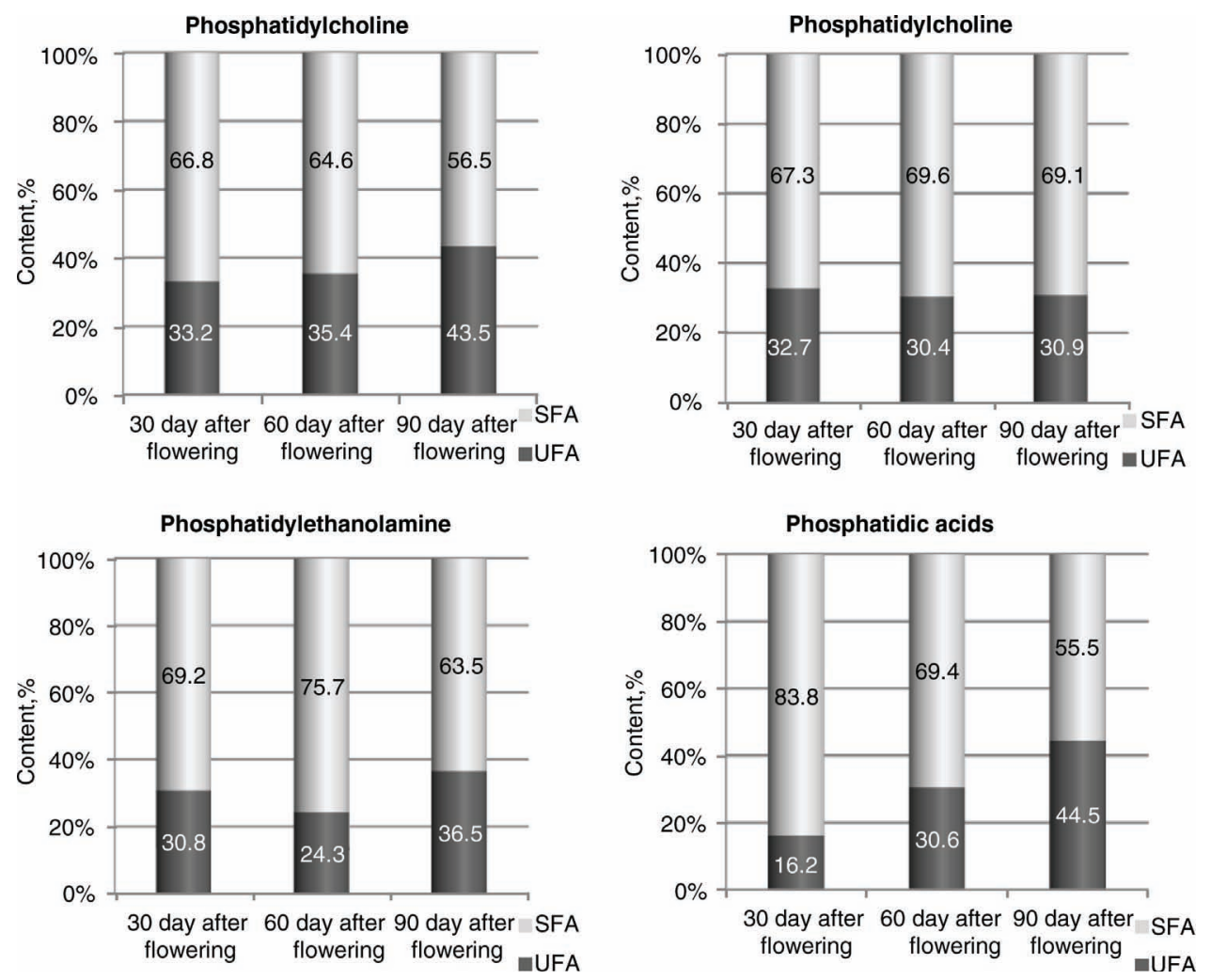

Figure 2. Saturated (SFA) and unsaturated (UFA) fatty acids in the main classes of phospholipids.

Phosphatidic acids, phosphatidylinositol, phosphatidylethanolamine, diphosphatidylglycerol and monophosphatidylglycerol predominated in the phospholipid fraction of the oil during the first stage of vegetation, while during the second and third stages of the growing season, the amounts of phosphatidylinositol, phosphatidylcholine and phosphatidylethanolamine increased. In the main classes of phospholipids, saturated fatty acids dominated in the three stages of the assay. Because of their high content of unsaturated acids, microelements and vitamins, pumpkin seeds and pumpkin seed oil are very healthy and can be used as a food or in medicine. 


\section{ACKNOWLEDGMENTS}

The investigations were carried out with the financial support of The Paisii Hilendarski University of Plovdiv, Scientific Research Department (SI 13 FC 006/2013).

\section{REFERENCES}

Aboul-Nasr MH, Ramadan BR, El-Dengawy RA. 1997. Chemical composition of pumpkin seeds. Assiut J. Agric. Sci. 28, 13-22.

Achu MB, Fokou E, Tchiegang Cl, Fotso M, Tchouanguep FM. 2005. Nutritive value of some Cucurbitaceae oilseeds from different regions in Cameroon. African J. Biotechnol. 4, $1329-1334$.

Achu MB, Fokou E, Tchiegang C, Fotso M, Tchouanguep FM. 2006. Chemical characteristics and fatty acid composition of Cucurbitaceae oils from Cameroon. IUFoST 2006, $13^{\text {th }}$ World Congress of Food Sci. Technol. DOI: 10.1051/ IUFoST: 20060026.

Al-Khalifa AS. 1996. Physicochemical Characteristics, Fatty Acid Composition, and Lipoxygenase Activity of Crude Pumpkin and Melon Seed oils. J. Agric. Food Chem. 44, 964-966. http://dx.doi.org/10.1021/jf950519s.

AOAC. 1995. Association of Official Analytical Chemists, Method. Washington, DC. $16^{\text {th }}$ edition.

AOAC. 1996. Association of Official Analytical Chemists. Method 945, 18-B, "Kjeldahl's method for protein determination in cereals and feed". $16^{\text {th }}$ edition.

Angelova-Romova M, Zlatanov M, Antova G, Momchilova S, Blagoeva E, Nikolova M. 2013. Phospholipids content and composition of hazelnut and walnut cultivars grown in Bulgaria. Comptes rendus de l'Académie bulgare des Sciences. 66, 1689-1694.

Ardabili AG, Farhoosh R, Haddad Khodaparast MH. 2011. Chemical composition and physicochemical properties of pumpkin seeds (Cucurbita pepo Subsp. Pepo Var. Styriaka) grown in Iran. J. Agr. Sci. Tech. 13, 1053-1063.

Bombardelli E, Morazzoni P. 1997. Cucurbita pepo L., Fitoterapia, 48, 291-302.

BS 13488:1976. Bulgarian State Standard. Grain. Method for determining the content of starch.

Codex standard for named vegetable oils. Codex-Stan 210-1999. Revisions 2001, 2003, 2009. Amendment 2005, 2011. p.16.

Fokou E, Achu MB, Tchounguep FM. 2004. Preliminary nutritional evaluation of five species of Egusi seeds in Cameroon. African J. Food, Agric., Nutrit. Develop. 4, 1-11.

Fokou E, Achu MB, Kansci G, Ponka R, Fotso M, Tchiegang C, Tchouanguep FM, 2009. Chemical properties of some Cucurbitaceae oils from Cameroon. Pakistan J. Nutrit. 8, 1325-1334. http://dx.doi.org/10.3923/pin.2009.1325.1334.

Folch J, Lees M, Sloane-Stanley GH. 1957. A simple method for isolation and purification of total lipids from animal tissues. J. Biol. Chem. 226, 498-509.

Islam S, Carvajal R, Carmen R, Garner JO, Jr. 2008. Physiological and biochemical variations in seed germination of
Cowpea (Vigna unguiculata L. Walp) cultivars. American J. Plant Physiol. 3, 16-24. http://dx.doi.org/10.3923/ ajpp.2008.16.24.

ISO. 1999. 12228:1999. Animal and vegetable fats and oils. Determination of individual and total sterols contents - Gas chromatographic method. 1999, p. 24.

ISO. 2000a. 5509:2000. Animal and vegetable fats and oils. Preparation of methyl esters of fatty acids. p. 30.

ISO. 2000b. 18609:2000. Animal and vegetable fats and oils. Determination of unsaponifiable matter. Method using hexane extraction. p. 8.

ISO. 2003. 10540-1:2003. Animal and vegetable fats and oils. Determination of phosphorus content - Part 1: Colorimetric method. p. 10.

ISO. 2004. 5508:2004. Animal and vegetable fats and oils. Analysis by gas chromatography of methyl esters of fatty acids. p. 9 .

ISO. 2006. 9936:2006. Animal and vegetable fats and oils. Determination of tocopherols and tocotrienols contents. Method using high-performance liquid chromatography. p. 17.

ISO. 2009. 659:2009. Oilseeds - Determination of oil content (Reference method). p. 12 .

Kamel SB, DeMan MJ, Blackman B. 1982. Nutritional, fatty acid and oil characteristics of different agricultural seeds. J. Food Technol. 17, 263-269. http://dx.doi. org/10.1111/j.1365-2621.1982.tb00181.x.

Kim MY, Kim EJ, Kim Y-N, Choi Ch, Lee B-H. 2012. Comparison of the chemical compositions and nutritive values of various pumpkin (Cucurbitaceae) species and parts. Nutr. Res. Pract. 6, 21-27. http://dx.doi.org/10.4162/ nrp.2012.6.1.21.

Lazos ES. 1986. Nutritional, fatty acid and oil characteristics of pumpkin and melon seeds. J. Food Sci. 51, 1382-1383. http://dx.doi.org/10.1111/j.1365-2621.1986.tb13133.x.

Martin FW. 1998. Cucurbit seed as possible oil and protein sources, Tropical seed.com.vegetables and herbs. ECHO; 17430. Durrance Rd, North FF. Myers FL33917, USA, p. 7.

Munshi SK, Sukhija PS, Bhatia IS, 1983. Lipid biosynthesis in developing kernels of almond (Prunus amygdalus), Phytochem. 22, 79-83. http://dx.doi.org/10.1016/ S0031-9422(00)80062-X.

Nakiae SN, Rade D, Kevin D, Strucelj D, Mokrove ak Z, Bartoliae M. 2006. Chemical characteristics of oils from naked and husk seeds of Cucurbita pepo L. Eur. J. Lipid Sci. Technol. 108, 936-943. http://dx.doi.org/10.1002/ ejlt.200600161.

Raharjo TJ, Nurliana L, Mastjeh S. 2011. Phospholipids from pumpkin (Cucurbita moschata (Duch.) Poir) seed kernel oil and their fatty acid composition. Indo. J. Chem. 11, 48-52.

Ryan E, Galvin K, O'Connor TP, Maguire AR, O'Brien NM. 2007. Phytosterol, Squalene, Tocopherol Content and Fatty Acid Profile of Selected Seeds, Grains and Legumes. Plant Foods Hum. Nutrit. 62, 85-91. http://dx.doi.org/10.1007/ s11130-007-0046-8.

Tsaknis J, Lalas St, Lazos E. 1997. Characterization of crude and purified pumpkin seed oil. Grasas Aceites 48, 267-272. http://dx.doi.org/10.3989/gya.1997.v48.i5.802. 